\title{
The Relationship Between School's Role in Monitoring Nutritional Status with Food Habit and Physical Activity of Primary School Students in Medan
}

\author{
Fitri Ardiani ${ }^{1}$, Rusmalawaty ${ }^{2}$ \\ ${ }^{1}$ Departement of Public Health Nutrition, University of Sumatera Utara, Indonesia \\ fit.ardiani@gmail.com \\ ${ }^{2}$ Departement of Administration and Health Policy, University of Sumatera Utara, Indonesia \\ fitri.ardianieusu.ac.id
}

\begin{abstract}
Nowdays, school is one of the environmental factors that affect the nutritional status of the student. The School Health Unit (UKS) and cafeteria as the school facilities, and extracurricular activities play an important role in achieving success in monitoring nutrition. The purpose of this study is to know the role of a school in monitoring the nutritional status and the food habit with physical activity of primary school students in Medan. This research with cross-sectional study of a representative sample of 210 primary school students. The sampling technique was purposive samplingmethod withconsidering the schools that have UKS and cafeteria where students can buy a wide variety of foods. Food habit of students collectedthrough interviews using food recall form. Physical activity was measured usingthe Physical Activity Level(PAL) formula. The role of schools in monitoringthe nutritional status is observed through the activities of UKS. Data were analyzeddescriptively using Chi Square to see the relationship between the school's rolein monitoring the nutritional status and the food habit and physical activity ofstudents. The results showed that the school which already has UKS was not monitoring the nutritional status of students, even though UKS already providing weight scales and microtoise for measuring the anthropometry students, so that the data of nutritional status of students are not available. The measurement of physical activity showed no significant relationship between the food habit of students seen from number of meals based on sufficiency energy, protein, and fat with physical activity $(p>0,05)$. It was concluded that the schools does not play a role in monitoring the nutritional status of students.
\end{abstract}

Keywords - Role of School, Monitoring of Nutritional Status, Dietary Habit, Physical Activity, Student

\section{INTRODUCTION}

Many studies show that the percentage of American children whose having overweight problem increased almost three times in the last 20 years. The tendency of children having overweight problem is because of consuming junk food, fast food and less exercise. In Indonesia, the people who experience overweight reach $21,7 \%$ and the number keep increasing every year. In 2010, the national prevalence of children nutrition at the age of 6-12 are $12,2 \%$ wasting, $78,6 \%$ normal, and 9,2\% overweight. Whereas at North Sumatera, the perevalence are $12 \%$ wasting, $77,5 \%$ normal ad $10,5 \%$ overweight. Nationally on Riskesdas 2013, the prevalence of wasting for the children at the age of 5-12 years old are $11,2 \%$. The overweight prolem of the children at the age of 5-12 is still high at $18,8 \%$, stand for $10,8 \%$ overweight and $8,8 \%$ obese [1].

Primary school children whether boys and girls that are in growing state is a valuable asset for the nation development in the future. The nutritional status of school children is determined by ideal consumption, besides parents influence, the awareness of the children itself is needed. The act of school is very important in determining the nutrition of the children. The existence of health facility at school is very helpful in organizing and monitoring the nutrition state of the children. The existence of school health unit, school canteen, extracurricular and other activities are very important in the success of nutrition monitoring.

One of the purpose of school health unit is for increasing the capability of healthy life. When the school citizen already have the awareness to live healthy, furthermore it is hoped that the school citizen especially teacher can increase their capability to live healthy. School health unit is not for nursing the sick anymore, but to curing the sick 
and increased the health who is already healthy. School health unit also participate in producing health standard optimally. In producing health standard, school health unit act in monitoring the nutritional status of the participant.

Medan is one of the region that is having development in Sumatera that supply health service centre or further health information and technology. There is a total of 843 school at Medan that spread around 21 subdistrict. However the development of school health unit at each school didn't get enough attention for it to function as it should be. Based on that fact, it is necessary to held a research about the school participation in monitoring the nutritional status of children and prevent the increase of nutrition problem prevalence especially in Medan City.

\section{METHODS}

This research was observational research with cross-sectional design, to see the connection between school participation in monitoring the nutritional status and physical activity with food habit and the nutritional status of school children. The process of selecting the schools were based on the purposive sampling method, that was, the school that school health unit and school canteen until selected 7 school that represent 21 sub-district in Medan. The withdrawal of sample was by using cluster sampling method and from each school 30 students were being picked, until it reached 210 students for research sample.

Data assemble method was with primary data and secondary data. Primary data included all research variable that is, data about food habit measured by using 24 hours food recall form and food frequency to see the amount, type, and frequency. The amount of food consumption was seen by the amount of energy, protein and fat that compatible with Number of Sufficient Nutrition. The frequency of eating was seen by how frequent someone consume certain food, type of food was seen by the variety of food that was being consumed. Physical activity was measured with Physical Activity Level (PAL) formula. Data about the school participation was gained by interviewing with questioner and open query.

The analysis of the data was done by univariat and bivariat, Bivariat analysis was done by using Chi Square Test to see the connection between food habit and physical activity of the students.

\section{RESULT AND DISCUSSION}

\section{A. Food Habit and Physical Activity}

TABLE I

Distribution OF FOOD HABIT AND PHYSICAL ACTIVITY PRIMARY SCHOOL STUDENTS

\begin{tabular}{|c|c|c|c|c|c|c|c|}
\hline \multirow[t]{3}{*}{ Food Habit } & \multicolumn{6}{|c|}{ Physical Activity } & \multirow{5}{*}{$\frac{\text { Sig }}{0.992}$} \\
\hline & \multicolumn{2}{|c|}{ Light } & \multicolumn{2}{|c|}{ Medium } & \multicolumn{2}{|c|}{ Heavy } & \\
\hline & $\mathrm{N}$ & $\%$ & $\mathrm{n}$ & $\%$ & $\mathrm{n}$ & $\%$ & \\
\hline Complete & 100 & 84.0 & 15 & 12.6 & 4 & 3.4 & \\
\hline Incomplete & 76 & 83.5 & 12 & 13.2 & 3 & 3.3 & \\
\hline
\end{tabular}

Based on the research, it was known that from 33 students in less category of sufficient energy, there was 26 students $(78,8 \%)$ with light physyical activity. While from 108 students with normal category, there are 91 students $(84,3 \%)$ with also light physical activitiy. In the more category, from
69 students, there were 59 students $(85,5 \%)$ with light physical activity. Based on the result of statistic test that used Chi-Square Test, it was found that there were no connection between the sufficient of energy with physical activity. $p=0,372>0,005$. 
TABLE II

Consumption of Energy, Protein, Fat and Physical Actitvity Distribution of Primary School Students

\begin{tabular}{|c|c|c|c|c|c|c|c|}
\hline \multirow{3}{*}{$\begin{array}{l}\text { Consumption } \\
\text { Of Nutrition } \\
\text { Substance }\end{array}$} & \multicolumn{6}{|c|}{ Physical Activity } & \multirow[t]{3}{*}{ Sig. } \\
\hline & \multicolumn{2}{|c|}{ Light } & \multicolumn{2}{|c|}{ Medium } & \multicolumn{2}{|c|}{ Heavy } & \\
\hline & $\mathrm{N}$ & $\%$ & $\mathrm{n}$ & $\%$ & $\mathrm{~N}$ & $\%$ & \\
\hline \multicolumn{8}{|c|}{ Energy Consumption } \\
\hline Less & 26 & 78.7 & 4 & 12.1 & 3 & 9.1 & \multirow[t]{3}{*}{0.372} \\
\hline Normal & 91 & 84.3 & 14 & 13.0 & 3 & 2.8 & \\
\hline More & 59 & 83.8 & 9 & 12.9 & 1 & 3.3 & \\
\hline \multicolumn{8}{|c|}{ Protein Consumption } \\
\hline Less & 39 & 81.2 & 6 & 12.5 & 3 & 6.2 & \multirow[t]{3}{*}{0.351} \\
\hline Normal & 70 & 83.4 & 11 & 12.9 & 4 & 4.7 & \\
\hline More & 67 & 87 & 10 & 13 & 0 & 0 & \\
\hline \multicolumn{8}{|c|}{ Fat Consumption } \\
\hline Less & 39 & 83.0 & 6 & 12.8 & 2 & 4.3 & \multirow[t]{3}{*}{0.441} \\
\hline Normal & 83 & 83.8 & 11 & 15.6 & 0 & 0 & \\
\hline More & 54 & 83.8 & 10 & 12.9 & 7 & 3.3 & \\
\hline
\end{tabular}

Based on the research, it was known that from 48 students in less category of sufficient protein, there was 39 students $(81,2 \%)$ with light physical activity. In the normal category, from 85 students, there were 70 students $(82,4 \%)$ with light physical activity. In the more category, from 77 students, there were 67 students $(87 \%)$ with light physical activity. Based on the result of statistic test that used Chi-Square Test, it was found that there were no connection between the sufficient of protein with physical activity. $\mathrm{p}=$ $0,351>0,005$.

Based on the research, it was known that from 47 students in less category of sufficient fat, there was 39 students $(83 \%)$ with light physical activity. While from 99 students with the normal category of sufficient fat, there were 83 students $(83,8 \%)$ with light physical activity. In the more category, from 64 students, there were 54 students $(84,4 \%)$ with light physical activity. Based on the result of statistic test that used Chi-Square Test, it was found that there were no connection between the sufficient of fat with physical activity. $\mathrm{p}=0,441>0,005$.

From Lia's research (2015) it was seen from the result that the connection between eating lifestyle and students's physical activity to study result of the students reached $53 \%$. From that result, it can be seen that there were no connection between food habit and students's physical activity with study result of the students. The student's study result was not only influenced by food habit and physical activity but also could be influenced by other factors, this matter was supported with the theory of Artianti Purborini in Lia (2015) that said, the children's growth is influenced by many factors, included nutrition, healthy physical environment, dan lack of food [2].

Almost all of the children had light physical activity, this matter was caused by the developing technology and everyday activity that was done. The developing technology like television, computer dan internet was the caused that many children became lazy to move [3]. Children were more interested to spent most of their time by doing passive activity, such as playing video games, online games, surfing the internet and watching televison, that everyday the children spent about 3 hours only to watch television. All of that passive activity didn't require much energy [4].

The recommended physical activity for children at the age of 1-5 are 3 hours of doing light activity such as walking dan split their time in a day. At the age of $5-12$, it is more than 1 hours and keep being increase to a few hours everyday to do light physical activity, such as cycling, running, climbing, jumping, climbing the stairs, and dancing [5].

According Simatupang, the problem of overweight that happen to the private primary school students at Medan Baru sub-district, was influenced by the variable of given fat, given energy, frequency of eating, type of food, and physical activity 
especially hard and medium physical activity, while the inheritance variable was not influential [6].

\section{B. School Participation in Monitoring the Nutrition Status}

The result of observation at all of the schools that had school health unit, it was found that there were weight scales and microtoice. Both the weight scales and microtoice were not being used to monitor the growth status of the student nutrition. The result from the interview with health clininc's teachers and the school's principal, said that the weight scales and microtoice were never used. Moreover at both of the schools, the weight scales and the microtoice weren't being allowed to be used by the students.

Based on the interview with the health clininc's teachers and the school's principal, it was found that the health clininc's teachers didn't participate in monitoring the nutritional status of the students. The school health unit teachers only act as guardian without doing any activity that related to measuring height and weight. The head of the school also didn't has any participation in monitoring the nutrition status of the students. The files about antrophometry data that was gained in the beginning of entering the school only became archives. The school's principal didn't understand that those file could be used as a tool to monitor the nutritional status of the students.

The efforts of guiding health for primary school students should be developed, considering that the group is very potential as the human resources in developing the country especially in the health sector. One of many ways to increased the quality of human resources is by giving health guide service for school students.

In conclusion, the participation and the new function that can be done by someone who works as health clininc's teacher that are in duty of and responsible are implementing the education about health to the students, until the healthy lifestyle is planted and become habits in the everyday life of the students.

\section{CONCLUSIONS}

The microtoice and weight scales that are in the school health unit is not being used by the school health unit's teachers to measure te antrophometry of the students, because of that, the school doesn't has data of monitoring the nutritional status and the antrophometry of the students. This matter shows that the school didn't participate in monitoring the student's nutrition.

\section{ACKNOWLEDGEMENT}

The writer would like to say thanks for Research Institution of University of Sumatera Utara that has gave donation untill this reseach could be finished, and also to the Dean Faculty of Public Health, University of Sumatera Utara that has gave permission to the writer to do the research. Besides that, the writer also would like to say thanks to all the students that has work together and voluteering as the object for this research.

\section{REFERENCES}

[1] Riskesdas (2013). Riset Kesehatan Dasar 2013 http://www.litbang.depkes.go.id Akses: 25 Mei 2016.

[2] Damayanti, A.D. (2008). Cara Pintar Mengatasi Kegemukan Anak. Yogyakarta: Curvaksara. Tersedia dalam http://repository.ipb.ac.id/bitstream/handle/123456789/2828/A08san2.p df; jsessionid=8B555CED09901 A5BEA59E343F6989C03 ?sequence $=5$ diakses pada tanggal 20 November 2016.

[3] Lia, N. A, 2015, Hubungan Pola Makan Dan Aktivitas Siswa Dengan Hasil Belajar Siswa Kelas V Di SDN Banjar tanggul Desa Banjar tanggul Kecamatan Pungging Kabupaten Mojokerto. Jurnal.Pendidikan Tata Boga, FakultasTeknik, Universitas Negeri Surabaya. Surabaya.

[4] Suci, D. F.Y. 2015. Hubungan Pola Makan Dan Aktivitas Fisik Dengan Kejadian Obesitas Pada Anak Di Sdn Nusawangi 3 Desa Nusawang Kecamatan Cisayong Kabupaten Tasikmalaya. Jurnal.Program Studi DIII Kebidanan STIKes Mitra Kencana Tasikmalaya.

[5] Bates H. 2006. Daily Physical Activity for Children and Youth [sintesis]. Alberta Education: Canadian Fitness and Lifestyle Research Institute: 9 18 .

[6] Simatupang M.R (2008). Pengaruh Pola Konsumsi, Aktivitas Fisik Dan Keturunan Terhadap Kejadian Obesitas Pada Siswa Sekolah Dasar Swasta Di Kecamatan Medan Baru Kota Medan. 